\title{
Research on Stock Adjustment Model of Chinese Pharmaceutical Industry in the Reforming Process of Mixed Ownership
}

\author{
Shengyi Shi ${ }^{1}$, Guangping Wang ${ }^{2}$, Yanfei Huo ${ }^{3}$, Baxian $\mathrm{Yi}^{3}$ \& Xiaoming $\mathrm{Wu}^{1}$ \\ ${ }^{1}$ China Pharmaceutical University, Nanjing, China \\ ${ }^{2}$ Shanghai Institute for Food and Drug Safety, Shanghai, China \\ ${ }^{3}$ China State Institute of Pharmaceutical Industry, Shanghai, China \\ Correspondence: Xiaoming Wu, China Pharmaceutical University, Nanjing 210009, China. E-mail: \\ xmwu@cpu.edu.cn
}

Received: July 13, 2016 Accepted: September 8, 2016 Online Published: October 31, 2016

doi:10.5539/par.v5n2p104 URL: http://dx.doi.org/10.5539/par.v5n2p104

\begin{abstract}
The aim of Chinese pharmaceutical industry restructuring and upgrading is to achieve the transformation from incremental expansion to the stock adjustment road. As the mail strength of industrial restructuring, pharmaceutical companies of state-owned and state-holding are the main object of pharmaceuticals industry mixed ownership reforms. Basing on the analyzing of mixed ownership reforming process and industry restructuring, the paper discussed the impacting factors of Chinese pharmaceutical restructuring with the empirical analysis of Panel Data model. Result display that the state-owned companies perform the more quantity, extensive mode of production, which need the stock adjustment model. Restructuring road include the incremental and stock adjusting, micro-stock adjusting, social capital participating and state-owned capital exchange building.
\end{abstract}

Keywords: ownership, pharmaceutical industry, stock adjustment, state-owned company

\section{Introduction}

In the third plenary session of $18^{\text {th }}$ the Communist Party of China (CPC) Congress, it has been definitely put forward to reforming the operation and management modes, getting rid of the monopoly and changing the past assets control to the capital control of state-owned enterprises, which would be benefit to strengthen the National Capital Control in future. Especially adopting the reform mode of the mixed ownership, it will stimulate the vitality of state-owned capital and promote social capital investment in a wider field operation. These would break the monopoly of state-owned enterprises gradually. Based on the policy target forwarded in the fifth plenary session of $18^{\text {th }}$ the CPC Congress, the economic structure should adjust from incremental expansions to Stock Adjustment and the state-owned enterprises would take an important role in this process. As one of the national high-tech industries, biomedicine enterprises should take this reformation opportunity, adopting the combination way of incremental expansions and Stock Adjustment to adjust the pharmaceutical industry structure and update the pharmaceutical economic.

\section{Reformation in Pharmaceutical Management System and Pharmaceutical Companies Ownership}

For a long time, it has been using Integration of government and enterprise mode for China's pharmaceutical management system. China's pharmaceutical management system has not been separated until 1998, and then the local pharmaceuticals and the state pharmaceuticals have just been built. The reformation of ownership for state-owned pharmaceuticals has been conducted step by step after the third plenary session of $12^{\text {th }}$ the CPC Congress, and deeply reformation in the mixed ownership has been conducted in the third plenary session of 18th the CPC Congress.

\subsection{System Evolution of the Medicine System Management Reform}

From 1949 to 1998, the management system for pharmaceutical industry is integration of government and enterprise mode in China. Since the founding of the People's Republic of China, the China's pharmaceutical industry, including the pharmaceutical business, traditional Chinese medicine, chemical pharmaceutical and medical devices, is belonged to the Ministry of Health, Ministry of Commerce and the Ministry of Chemical 
Industry. In the August of 1950 the Chinese pharmaceutical companies was set up to supervise the national pharmaceutical distribution around China. In 1964, the country piloted pharmaceutical industry (Trusts), such as established the Chinese pharmaceutical industry companies, which aiming to centralize leadership and professional management (Figure 1). In 1998, it was forwarded in the "Government Work Report" of $7^{\text {th }}$ National People's Congress meeting that the key to reform is the separation of ownership and management of enterprises." In late 1998, the former State Pharmaceutical Administration of China directly under the Pharmaceutical Industry Corporation, China Pharmaceutical (Group) Corporation, China National Pharmaceutical Foreign Trade Corporation, and China National Medical Equipment Industry Corporation founded the China Pharmaceutical Group Corporation, which directly managed by the State-owned Assets Supervision and Administration Commission of the State Council (SASAC). It marks the termination of medical management era of integration of government and enterprise mode. Pharmaceutical management system of integration of government and enterprise mode for all provinces gradually evolved into local state-owned and state-holding pharmaceutical companies, such as Shanghai Pharmaceutical Group, Nanjing Pharmaceutical Group, and this denoted the industry entering a fully competitive pharmaceutical production and operation of rapid development stage.

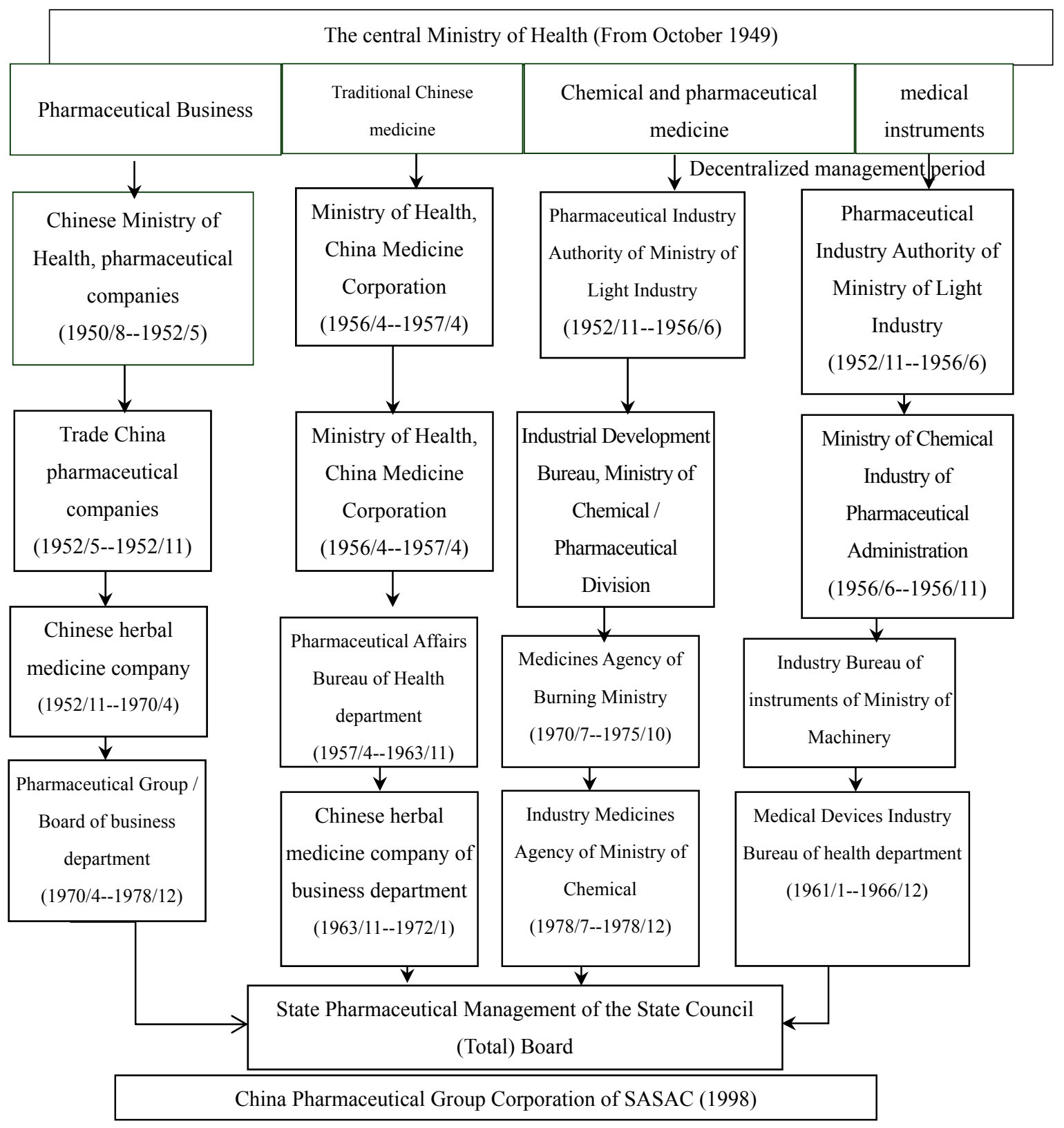

Figure 1.The evolution diagram of the Chinese medicine management system 


\subsection{Ownership Reform of Chinese Pharmaceutical Enterprises}

In order to establish a unified, efficient production management system, the pharmaceutical industry implements the spirit of the third plenary Session of the $12^{\text {th }}$ the CPC congress, medical director of state-owned industrial enterprises to implement the responsibility system, pharmaceutical commercial enterprises manager responsibility system in 1985. It approaches to develop the horizontal economic integration by using the attraction outside investment and combination of state investment. In 1987, through a number of horizontal economic coalitions of pharmaceutical conglomerate and in accordance with the principle of the separation of ownership and management, pharmaceutical companies gradually construct responsibility system. Around 1989, the state funded the well-known international pharmaceutical companies established a joint venture in Wuxi Huarui, Shanghai Squibb, GlaxoSmithKline, Chongqing, Xian-Janssen, capsules Suzhou, Tianjin Smith Kline and other nine joint ventures. In July 1992, as the transformation of operating mechanism Ordinance of state-owned industrial enterprises enacted, the pharmaceutical industry set up enterprise groups and joint-stock reform deeper and deeper, such as Northeast Pharmaceutical Group, North China Pharmaceutical Group, Xinhua Pharmaceutical Group, Shanghai Pharmaceutical Industry Group, and Stock was implemented in some of these companies. After Deng Xiaoping's southern tour speech, the foreign investment and joint ventures around the medicine were accelerated gradually. In November 1993, the third plenary session of $14^{\text {th }}$ the CPC Congress has forwarded the target of "further conversion of state-owned enterprise management mechanism" (Table 1). In January 1997, Chinese medicine was focused on the ways to accelerating the economic restructuring in the Conference of Directors of National Medical Management. In August, the principles of structural adjustment were shown as: incremental and stock simultaneously development, but the stock for main purpose, the equity and debt both for development, but the equity for main purpose. In late 1998, the four state-owned pharmaceutical companies set up central China Pharmaceutical Group Corporation, directly managed by the SASAC. In September 1999, the fourth plenary session of the $15^{\text {th }}$ the CPC Congress further emphasized state-owned enterprises as the backbone of the national economy, as well as reform and development issues of state-owned enterprise. According to the meeting, the pharmaceutical industry should actively promote the joint between enterprises and reorganizations. The third plenary session of $18^{\text {th }}$ the CPC Congress proposed the development of "state capital, collective capital, private capital and other cross-shareholdings, and mutual integration of mixed ownership economy". In August 2015, "the CPC Central Committee, State Council guidance on deepening the reform of state-owned enterprises" forwarded that the state capital layout structure of state-owned assets management system, the modern enterprise system, and market-oriented operation mechanism is more reasonable. In September 2015, based on "category" and "layered" two dimensions of view, "the State Council on the development of state-owned enterprises of mixed ownership economy opinions", fixed the mixed ownership reform of state-owned space roadmap, which would further promote the state-owned enterprise ownership reformation. 
Table 1. Main guidelines for State owned enterprise reforming from 14th CPC Congress to 18th CPC Congress

\begin{tabular}{|c|c|c|}
\hline & Ownership Structure & state-owned enterprise reformation \\
\hline 14th the Communist Party of China & $\begin{array}{l}\text { On the ownership structure, Owned and } \\
\text { collectively owned economy are the main } \\
\text { body of Public Ownership and the } \\
\text { Individual economy, private economy, } \\
\text { foreign economic are the supplement }\end{array}$ & $\begin{array}{l}\text { State-owned enterprises, collective } \\
\text { enterprises and other companies play a } \\
\text { leading role in state-owned enterprises by } \\
\text { fair competition in the market. }\end{array}$ \\
\hline 15th the Communist Party of China & $\begin{array}{l}\text { Stock is a form of capital organization of } \\
\text { modern enterprises. It is conducive to the } \\
\text { separation of ownership and management, } \\
\text { and it improves the operational efficiency of } \\
\text { enterprises and capital. }\end{array}$ & $\begin{array}{l}\text { State and collective holding enterprise has } \\
\text { obvious public nature. Promote and } \\
\text { encourage workers labor union and workers } \\
\text { joint capital-based of collective economy. }\end{array}$ \\
\hline 16th the Communist Party of China & $\begin{array}{l}\text { Central and local government perform the } \\
\text { function on behalf of the State, enjoy the } \\
\text { owner's equity; Separating the government } \\
\text { and enterprise, and implementing the } \\
\text { separation of ownership and management } \\
\text { rights }\end{array}$ & $\begin{array}{l}\text { Concern the national economy and national } \\
\text { security of the large state-owned enterprises } \\
\text { and infrastructures, central government } \\
\text { performs the function on behalf of the State. }\end{array}$ \\
\hline 17th the Communist Party of China & $\begin{array}{l}\text { Introducing competition and strengthening } \\
\text { government regulation and public oversight } \\
\text { to deepen the reform of monopoly } \\
\text { industries. Improve all kinds of state-owned } \\
\text { assets management systems. }\end{array}$ & $\begin{array}{l}\text { Deepening the reform of state-owned } \\
\text { joint-stock system; Improving the modern } \\
\text { enterprise system; Optimizing the layout and } \\
\text { structure of the state economy. }\end{array}$ \\
\hline 18th the Communist Party of China & $\begin{array}{l}\text { Consolidate and develop the public } \\
\text { economy and promote multiple forms of } \\
\text { public ownership. Encourage, support and } \\
\text { guide the development of non-public } \\
\text { economic. }\end{array}$ & $\begin{array}{l}\text { State-owned capital invests to the important } \\
\text { industry and key fields related to the } \\
\text { national security and national economy. }\end{array}$ \\
\hline
\end{tabular}

\section{Industrial Structure Adjustment of Ownership System Reform}

The main direction for the pharmaceutical manufacturing restructuring is to change the mode of economic development and industrial upgrading, and also should shift the incremental expansion to stock adjustment for medicine industries. Differ from the macroeconomic structural adjustment, the pharmaceutical industry structural adjustment is the median level. However, the effect of structural adjustment of the ownership structure depends on the adjustment of ownership structure in the micro level.

\subsection{Background of Pharmaceutical Industry Structure}

In the fifth plenary session of $17^{\text {th }}$ the CPC Congress, it proposed "speed up the transformation of economic development is the core mission to promote industrialization," which is different from the "Ninth Five-Year Plan", which proposed "growth mode should from extensive to intensive ". This change of the concept for the mode of economic development includes productive development and social development and so on. In October 2010, the policy objectives were denoted in the "Guideline on accelerating the restructuring of the pharmaceutical industry", which include that promoting the optimization and upgrading of the structure of the pharmaceutical industry, and that adjusting the product structure, technological structure, organizational structure, regional structure and export structure. Based on the pharmaceutical industry structure adjustment and upgrading of basic conditions, the transformation of economic development of medicine was accelerated in the "Twelve-Five Plan" period. In this period, the pharmaceutical industry structure adjustment was promoted by "incremental to stock" mode. In the fifth plenary session of $18^{\text {th }}$ the CPC Congress, it proposed the main object is to re-adjustment of the economic structure from incremental expansion to the adjustment of stock and optimization of incremental simultaneously. The number of pharmaceutical manufacturing industry state-owned enterprises and foreign-funded enterprises were in a scissors trends in 2000-2014, and the foreign-funded enterprises profit growth is significantly faster than the state-owned enterprises (Figures 2 and 3). The number of corporate units was in an uneven development level for the state-controlled provinces, so we should adjust the 
diverse forms of ownership association from the macro level to drive stock adjustment, from the micro level through inter-enterprise reform, merger, share holding, acquisitions and stock to adjust the medical economics stock.

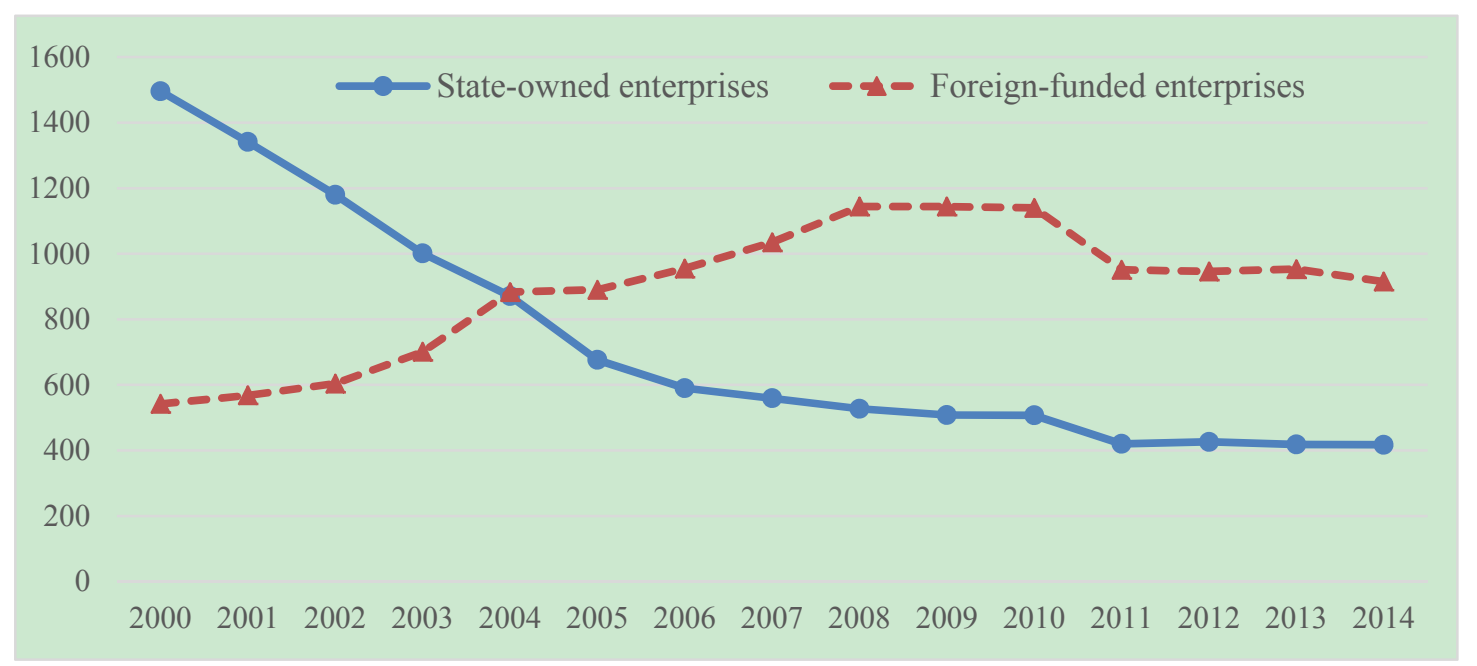

Figure 2. The quantity of ownership structure for pharmaceutical manufacturing

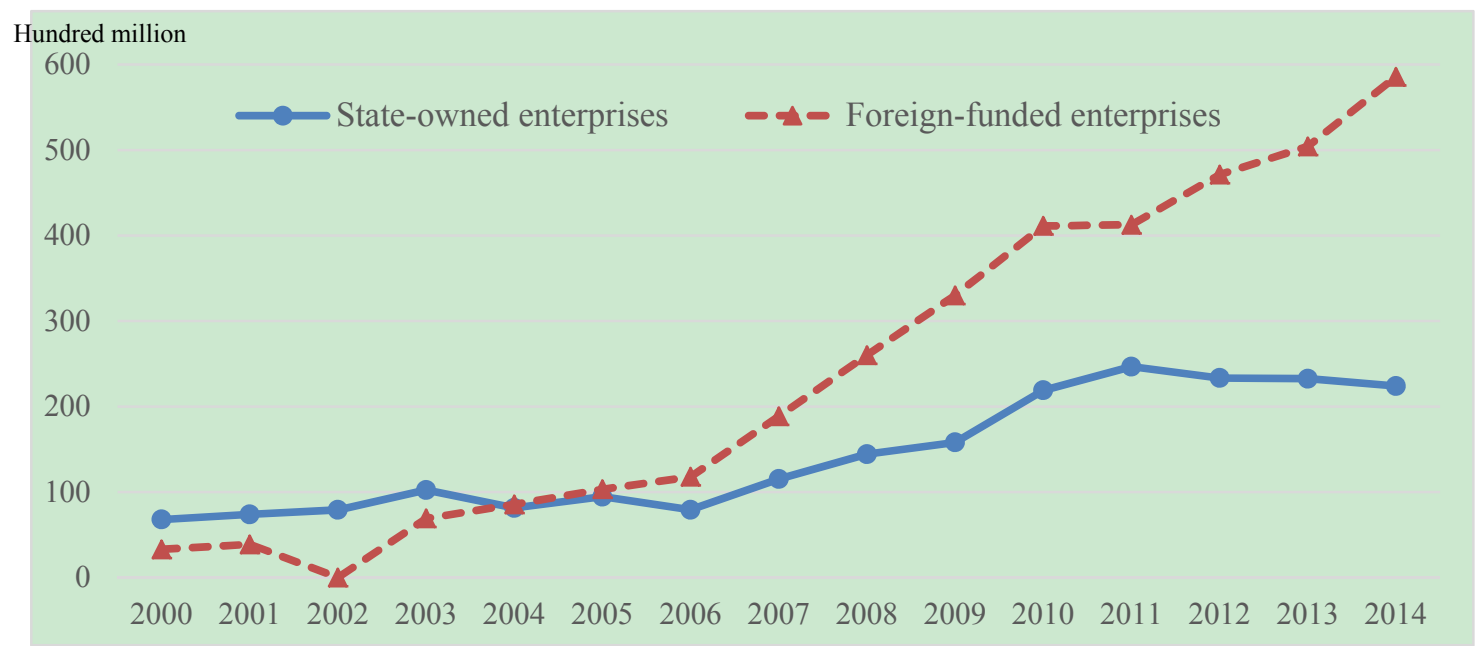

Figure 3. The profit of ownership structure for pharmaceutical manufacturing

Source: China Statistical Yearbook on High Technology Industry (2015).

\subsection{Ownership Structure Adjustment Ways}

Deepening ownership restructuring should focus on the stock adjustment of the ownership restructure ${ }^{[1]}$ As one of high-tech industries, the Industrial restructuring for Pharmaceutical manufacturing in different from the structural adjustment for other industries in macroeconomic level. In details, the Industrial restructuring for macroeconomic industries is based on the Primary industry, secondary industry and tertiary industry, which is Agriculture industry, industry, services industry. They analyzed the allocation structure, imports and exports, consumption structure, technological structure and labor structure to adjust the industrial structure. However, the Industrial restructuring of Pharmaceutical manufacturing is based on the median level, the effect of structural adjustment depends on the ownership structure of the micro-level adjustment. So, Industrial restructuring is not only the incremental changes in fixed asset investment flows, but also consider the stock of assets adjusted. That is to say, assets should be restructured across sectors, regions and enterprises ${ }^{[2]}$. According to the State Ministry "Guideline on accelerating the restructuring of the pharmaceutical industry," the pharmaceutical industry structure including product mix, technological structure, organizational structure, regional structure. Ma Kai (1997) believed that the restructuring ways including two aspects about the stock adjustment and the incremental adjustment ${ }^{[3]}$, and in the general practice of structural adjustment, it can take a four combinations way, and in 
this way of the "incremental to stock mode" and "stock to increment mode" is an optimization process.

Industrial structure adjustment is mainly based on regional structure adjustment in macro level, but the organizational restructuring and structural adjustments of techniques are in median level. Mergers and acquisitions among pharmaceutical companies are in micro level, that is enterprise ownership restructuring. They are mutually symbiotic and coordinated development for Cross-regional mergers and acquisitions among provinces in cooperation with the merger and reorganization of enterprises but not independent. Pharmaceutical ownership reform is consistent with the overall ownership reform for the national industry. The characteristics of our nation reform are the combination of Radical reform and gradual on control over the ownership reform ${ }^{[4]}$, which is different from Eastern Europe in the 1980s on the reform of state-owned enterprises.

\section{An Empirical Analysis of Industry Ownership Structure Adjustment Perspective}

Ownership and restructuring of resource elements having a certain relevance, if the ownership structure is different, the pharmaceutical industry restructuring will also not be the same. Adjusting the stock to achieve economic restructuring and industrial upgrading, which would be benefit to change the numerous and extensive mode of production situation for pharmaceutical enterprise.

\subsection{Overview on Impact of Ownership Structure on Industrial Adjustment}

To achieve the pharmaceutical industry structure adjustment and upgrading, there are two ways about the stock adjustment and the incremental adjustment. From Resource use perspective, we can get it by the combination of stock adjustment and incremental adjustments. From Endowment elements perspective, we can get it by the organization combination, technology, products and regions. There are little literature reviews on pharmaceutical industry ownership structure and restructuring. Wang guangping $(2014,2015)$ only analyze the organization structure, technical structure and the adjustment of product structure of pharmaceutical industry, but not deeply analyze the enterprise capital structure in terms of organizational structure ${ }^{[5,6]}$. Xu huaifu (2015) found that the medicine degree of economic development and the convergence trend are in opposite directions from the regional distribution structure view ${ }^{[7]}$. Hu jinyun (2014) believed that Equipment, technology, and independent innovation will promote industrial restructuring and upgrade the Traditional Chinese Medicine ${ }^{[8]}$. Zhong jingwen (2012) believed that there are large differences affect the nature of ownership of capital structure and its dynamic adjustment, and these factors including total assets, sales expenses and fixed assets ${ }^{[9]}$. Fang junxiong (2007) believed that State-owned enterprises are easier access to longer term bank loans than foreign-funded enterprises ${ }^{[10]}$. Fama and Frech (2002) analyzed the factors affecting the target capital structure, from enterprise scale, product competitiveness and profitability aspects ${ }^{[11]}$.

\subsection{Assumptions and Index Selection}

Pharmaceutical industry structural adjustment is an important way to change the mode of development and industrial upgrading. Under way to reform the ownership conditions, Pharmaceutical industry restructuring are different in terms of obtaining resources and also different enterprise profit will be occurred, these resources are mainly performed in human resources, enterprise scale, fixed assets, provision of new products aspects. Therefore, Pharmaceutical industry profits are the main object of pharmaceutical business ownership and direction of the adjustment results. Explore the impact of the pharmaceutical development of pharmaceutical industry on the economical profit in resource endowments and make full use of forms of ownership would achieve structural adjustment of inventory adjustment policy objectives for Pharmaceutical industry.

This study take profit (PROFIT) as the dependent variable to construct Panel Data model ${ }^{[12]}$ and take the number of employee (Employee), the number of enterprise (Enterprise), Investment in Fixed Assets (Invest), New product development funds (Newfee), Technological innovation funding (Tech) as Independent variable, and take 4 types of Ownership as the Cross-sectional objectives (Funded enterprises, state-owned enterprises, Hong Kong, Macao and Taiwan-funded enterprises, foreign-funded enterprises). By using the panel data from 2006 to the September of 2014 to build the basic regression equation for Quantitative analysis (following formula), where, $C$ is the constant term, a is coefficient, $t$ is sequentially, $i$ is the type of ownership.

$$
\begin{gathered}
\text { PROFIT }_{i t}=a_{0} C_{i t}+a_{1} \text { Employee }_{i t}+a_{2} \text { Enterprise }_{i t}+a_{3} \text { Invest }_{i t}+a_{4} \text { ANewfee }_{i t}+a_{5} \text { Tech }_{i t} \\
i=1,2, \ldots, 4
\end{gathered}
$$

\subsection{Model and Analysis}

This study select sample time dimension is 9 years; cross-sectional dimensions are four types of ownership and using the EViews7.0 software to conduct Panel Data Analysis. For get further analysis the relationship and the affection of the industry incrementally on profits of pharmaceutical industry, this study adopt the deformed 
model $\left(F_{2}=39.56>F_{2 \alpha}(18,12) ; F_{1}=22.40>F_{1 \alpha}(15,12)\right)$. At last, the result of the regression noted that fit of the regression equation is better, and the adjustment $R^{2}=0.9990, D W=3.33$.

Take the profit of Pharmaceutical companies as the dependent variable, the result is that:

From the number of employees perspective, State-owned enterprises and domestic enterprises are significantly positive correlation; From the number of enterprises, State-owned enterprises and domestic enterprises are negatively correlated; From Investment in fixed assets, State-owned enterprises is negatively correlated, however, foreign enterprises is positively correlated; From new product development costs, State-owned enterprises are positively correlated; From transformation costs, It is negatively correlated with state-owned enterprises and domestic enterprises.

Table 2. The regression results of Medicine Economic Development for Industrial Structure

\begin{tabular}{|c|c|c|c|c|}
\hline Variables & Regression coefficients & $\mathrm{R}$ & t-value & T-Probability \\
\hline \multicolumn{5}{|l|}{ Constant } \\
\hline Domestic enterprises & -2103.698 & 199.5045 & -10.54461 & 0.0000 \\
\hline State-owned enterprise & 156.4466 & 97.68159 & 1.601598 & 0.1352 \\
\hline \multicolumn{5}{|c|}{ Hong Kong, Macao and Taiwan } \\
\hline Foreign companies & -157.9750 & 62.90037 & -2.511511 & 0.0273 \\
\hline \multicolumn{5}{|l|}{ Employees } \\
\hline Domestic enterprises & 0.003198 & 0.000284 & 11.27997 & 0.0000 \\
\hline State-owned enterprise & 0.001316 & 0.000439 & 2.995354 & 0.0112 \\
\hline \multicolumn{5}{|c|}{ Hong Kong, Macao and Taiwan } \\
\hline Foreign companies s & 0.000433 & 0.000745 & 0.580845 & 0.5721 \\
\hline \multicolumn{5}{|l|}{ Quantity of enterprise } \\
\hline Domestic enterprises & -0.165375 & 0.024394 & -6.779289 & 0.0000 \\
\hline State-owned enterprise & -0.678978 & 0.195369 & -3.475360 & 0.0046 \\
\hline \multicolumn{5}{|c|}{ Hong Kong, Macao and Taiwan } \\
\hline Foreign companies & 0.158855 & 0.118749 & 1.337734 & 0.2058 \\
\hline \multicolumn{5}{|c|}{ Investment in Fixed Assets } \\
\hline Domestic enterprises & 0.042803 & 0.038997 & 1.097597 & 0.2939 \\
\hline State-owned enterprise & -0.341340 & 0.124532 & -2.740981 & 0.0179 \\
\hline \multicolumn{5}{|c|}{ Hong Kong, Macao and Taiwan } \\
\hline $\begin{array}{l}\text { enterprises } \\
\text { Foreign companies }\end{array}$ & $\begin{array}{l}0.321290 \\
1.106273\end{array}$ & $\begin{array}{l}1.010276 \\
0.529424\end{array}$ & $\begin{array}{l}0.318022 \\
2.089580\end{array}$ & $\begin{array}{l}0.7559 \\
0.0586\end{array}$ \\
\hline \multicolumn{5}{|c|}{ Funding for new production } \\
\hline Domestic enterprises & -0.000223 & 0.000144 & -1.554198 & 0.1461 \\
\hline State-owned enterprise & 0.000477 & 0.000163 & 2.932107 & 0.0126 \\
\hline \multicolumn{5}{|c|}{ Hong Kong, Macao and Taiwan } \\
\hline \multicolumn{5}{|c|}{ Funding for technological } \\
\hline \multicolumn{5}{|l|}{ Foreign companies } \\
\hline Domestic enterprises & -0.000413 & 0.000131 & -3.141023 & 0.0085 \\
\hline State-owned enterprise & -0.000748 & 0.000226 & -3.311658 & 0.0062 \\
\hline \multicolumn{5}{|c|}{ Hong Kong, Macao and Taiwan } \\
\hline enterprises & 0.000971 & 0.000604 & 1.607348 & 0.1340 \\
\hline Foreign companies & 0.000273 & 0.000477 & 0.571830 & 0.5780 \\
\hline \multicolumn{2}{|c|}{$\mathrm{R}^{2}=0.999651$} & \multicolumn{3}{|c|}{ Adjusted $\mathrm{R}^{2}=0.998983$} \\
\hline $\mathrm{P}(\mathrm{F}$ & $=0.000000$ & D-W Statis & $=3.334243$ & \\
\hline
\end{tabular}

\subsection{Results and Conclusions}

After the Empirical Analysis of panel date model regression for Pharmaceutical companies profits and Industrial 
Structure Adjustment of resource elements, the results noted that there is a certain relevance among State-owned enterprises and domestic enterprises and the restructuring of resource elements. Therefore, in the process of ownership reformation, by using stock or incremental adjustment of resource elements to get the result of government macro-control, State-owned enterprises can achieve the economic restructuring and industrial upgrading for Medicine industry.

1) The total profits of state-owned and domestic pharmaceutical enterprises is negatively correlated with the number of enterprises, technological innovation fund, but it is positively correlated with the number of employees. However, there is no correlation among the total profit of Hong Kong, Macao, Taiwan and foreign enterprises and the number of enterprises, technological innovation funding, and the number of employees. So, we can conclude that the state-owned enterprises are also mainly in a numerous and Extensive mode of production, which is need to Merger and reform mixed ownership to adjust the stock and improve the economic profit for pharmaceutical enterprises.

2) Total profits of state-owned pharmaceutical enterprises are negatively correlated with the investment in fixed assets, but there is there is no correlation between the domestic enterprises and the Hong Kong, Macao and Taiwan-funded enterprises. This denoted in access to resources, state-owned pharmaceutical companies have more advantages than Hong Kong, Macao and Taiwan-funded enterprises and it also need to adjust the stock to promote the structure adjustment and industry updating for state-owned pharmaceutical companies.

3) In the total profits and financing new product development aspects, State-owned pharmaceutical companies are positively correlated, but there are no correlations between Domestic, Hong Kong, Macao, Taiwan and foreign companies. So, new product development activities for state-owned pharmaceutical companies will promote the profit growth of State-owned pharmaceutical companies.

\section{Path analysis for Stock Adjustment of Pharmaceutical Industry Ownership Reform}

Related to the national ownership reform policies, the choice of way to adjust the industry structure for pharmaceutical industry is to drive from the incremental to stock in the regional structure aspect, mergers and restructures in micro level, Encourage social capital to participate in and Construct state-owned mobile platform.

\subsection{Incremental Integration Driven by the Stock of Resource Endowments}

During the "Twelve Five-year Plan" period, the main characteristics of the Pharmaceutical industry in the transformation of economic growth way are the pharmaceutical industry restructuring and Incremental drive stock, and it is mainly performed on the Integration and optimization of resources endowment in the regional economics. There are two ways to denote the adjustment of industry structure for pharmaceutical industry in the Incremental drive stock mode. One way is to Integrate and digest the endowment of resources by local government. Another way is to mergers and restructures the enterprises in their fixed ownership reformation process based on the micro level.

It is unbalanced in regional development of China's pharmaceutical industry. There is an obviously advantage in the Innovation Efficiency (Income of Sales new products/ Researchers) and Industrial efficiency (output value/Practitioners) than Central regional, western regional and northeast of China. From the table we can found that asset utilization is higher in Central Region than other regionals; Pharmaceutical industrial base in Northeast China is better, but innovation is weaker than in other regions (Table 3). He daan (2005) believed that the stock of fixed assets and restructuring were not transferable lifetime reality will hinder the optimal combination of factors of production and technology updates ${ }^{[13]}$. Based on the differences in the regional technology and differences endowment of resources in structure, taking up the Incremental drive stock for economic growth is an efficient way to realize the pharmaceutical industry restructuring. Although the main Contradictions and difficulties focus on the unreasonable Capital stock of industry for the adjustment of industry structure, there is a significant influence for the flaws of Incremental capital to the adjustment of industry structure ${ }^{[14]}$. The updating of industry for the Incremental drive stock mode is mainly update and promote the development of the pharmaceutical industry and optimize the industrial structure medicine by attracting the outside investment. 
Table 3. The situation of regional pharmaceutical manufacturing industrial productivity, Efficient use of resources and Innovation Efficiency

\begin{tabular}{llll}
\hline Regional & $\begin{array}{l}\text { Output / employees } \\
\text { thousand yuan / person) }\end{array}$ & $\begin{array}{l}\text { Profits / assets } \\
\text { (Ten thousand / one hundred } \\
\text { million yuan }\end{array}$ & $\begin{array}{l}\text { Sales of new products / } \\
\text { researchers } \\
\text { (Ten thousand / person) }\end{array}$ \\
\hline The national average & 97.22 & 1767.82 & 714.15 \\
East Region & 109.22 & 1746.26 & 837.66 \\
Central Region & 85.64 & 1887.34 & 637.54 \\
Western Region & 77.30 & 1716.15 & 586.63 \\
North-east Region & 100.95 & 1777.94 & 348.92 \\
\hline
\end{tabular}

Source: China Statistical Yearbook on High Technology Industry (2015).

\subsection{Way for Enterprises Stock Adjustment in the Micro Level}

Economic restructuring is to adjust the structure of the stock on earth, and the incremental adjustment is the boosters for stock adjustment. In the early reformation of China's ownership, it is an incremental reformation in first and the stock reformation followed way. Ma Kai (1997) believed that because of the historical and institutional, it is unbalanced in Industrial Distribution and corporate layout for State-owned Assets, which can be invigorated for assets stock and state-owned Assets stock by using various reformations of ownership type, such as: Syndicate, mergers, equity holding, acquisition, auction. This would adjust the organizational structure and promote the optimization of industrial structure. Wu Yue (2014) proposed that the incremental reformation should in first and the stock reformation of state-owned enterprises should be followed it for fixed ownership reformation.

In the micro level, the process of mixed ownership reformation become one of the most popular modes in the pharmaceutical industry adjustment and the local practice is featured as mergers and restructuring to proceed the reformation of mixed ownership. Optimize the organizational structure and speed up the upgrading of industrial structure adjustment is also forwarded in the "Twelfth Five-year Plan for pharmaceutical industry" and "National Development Plan for pharmaceutical distribution industry". Zhong jingwen (2012) believed that the nature of corporate ownership has significant influence on the corporate operation and performance. In the micro level, the process of mixed ownership reformation become one of the most popular modes in the pharmaceutical industry adjustment and the local practice is featured as mergers and restructuring to proceed the reformation of mixed ownership. The transformation from incremental adjustments to the stock of inventories was the main direction during the period of "Thirteen Five-year Plan" for the industry structure adjustment, which was forward in the fifth plenary Session of 18 th CPC Congress.

\subsection{Capital Stock Adjustment Model of Social Participation}

Consumption, investment, net exports are the main three modes in promoting economic growth. Recently the consummation of medicine production trends a stable growth. The investment and net exports become an important way for medicine economic growth. After the $21^{\text {st }}$ century, China's manufacturing industry increased fixed assets investment in the proportion of total new investment rising rapidly, domestic enterprises accounted for a large proportion of private capital in the ownership structure of the absolute proportion (Figure 4 and Figure 5). The social capital plays an important role in the pharmaceutical industry restructuring; therefore, it is necessary to play the active role in social capital stock adjustment. However, the uncertainty of the market environment, asymmetric information, bounded rationality and private actors would influence the effect of pharmaceutical manufacturing assets inventory adjustment. In the third plenary session of 18th CPC Congress, It is proposed that handle the relationship between government and the market, and Make the market play a decisive role in the allocation of resources and better play the role of government. To a conclusion, in the process of social capital, which plays an important role in the stock adjustment of the medicine industry, the government should strengthen the policy guideline and solve the problems between market basic construction and information service, which would reduce the impact of adverse market environment factors on the participation of social capital stock adjustment. 


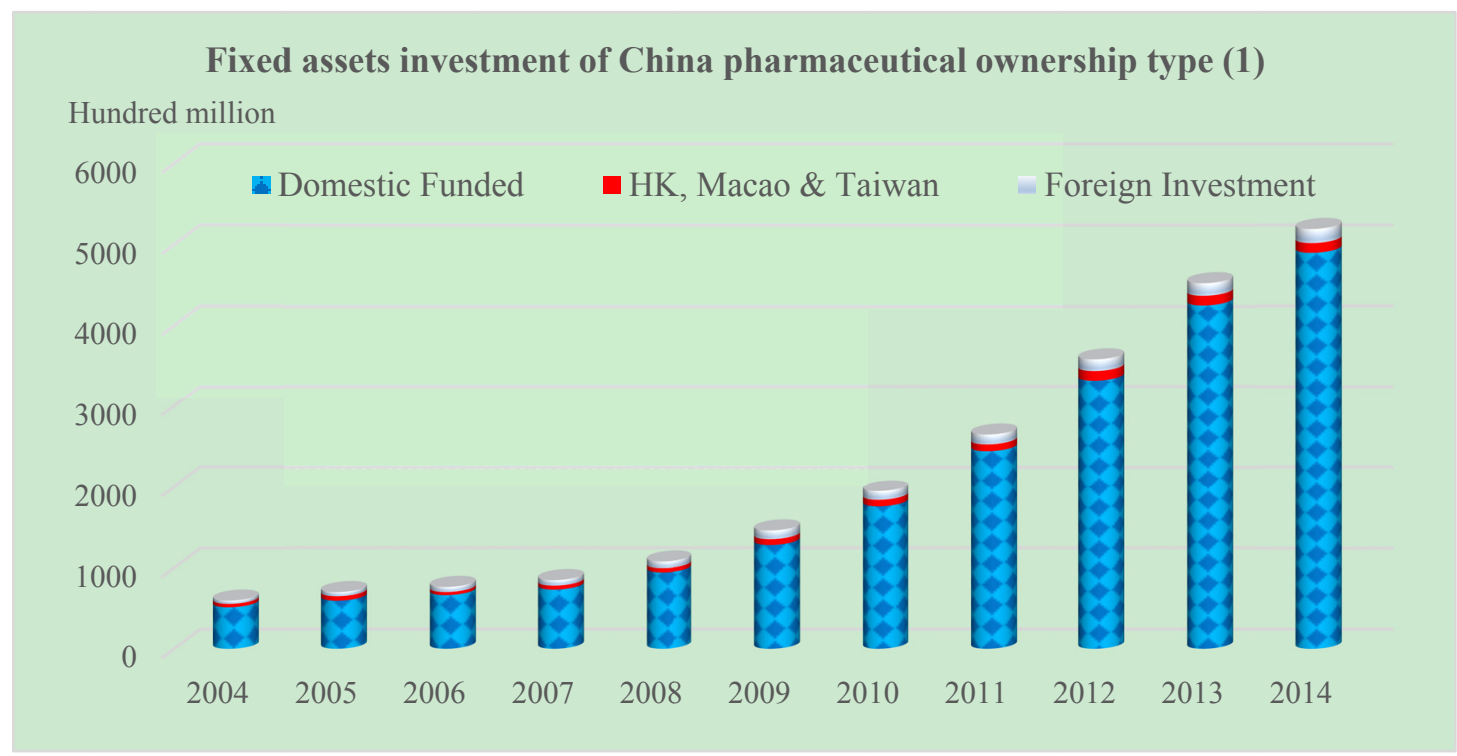

Figure 4. The foreign investment in fixed assets of pharmaceutical industry

Source: China Statistical Yearbook (2015).

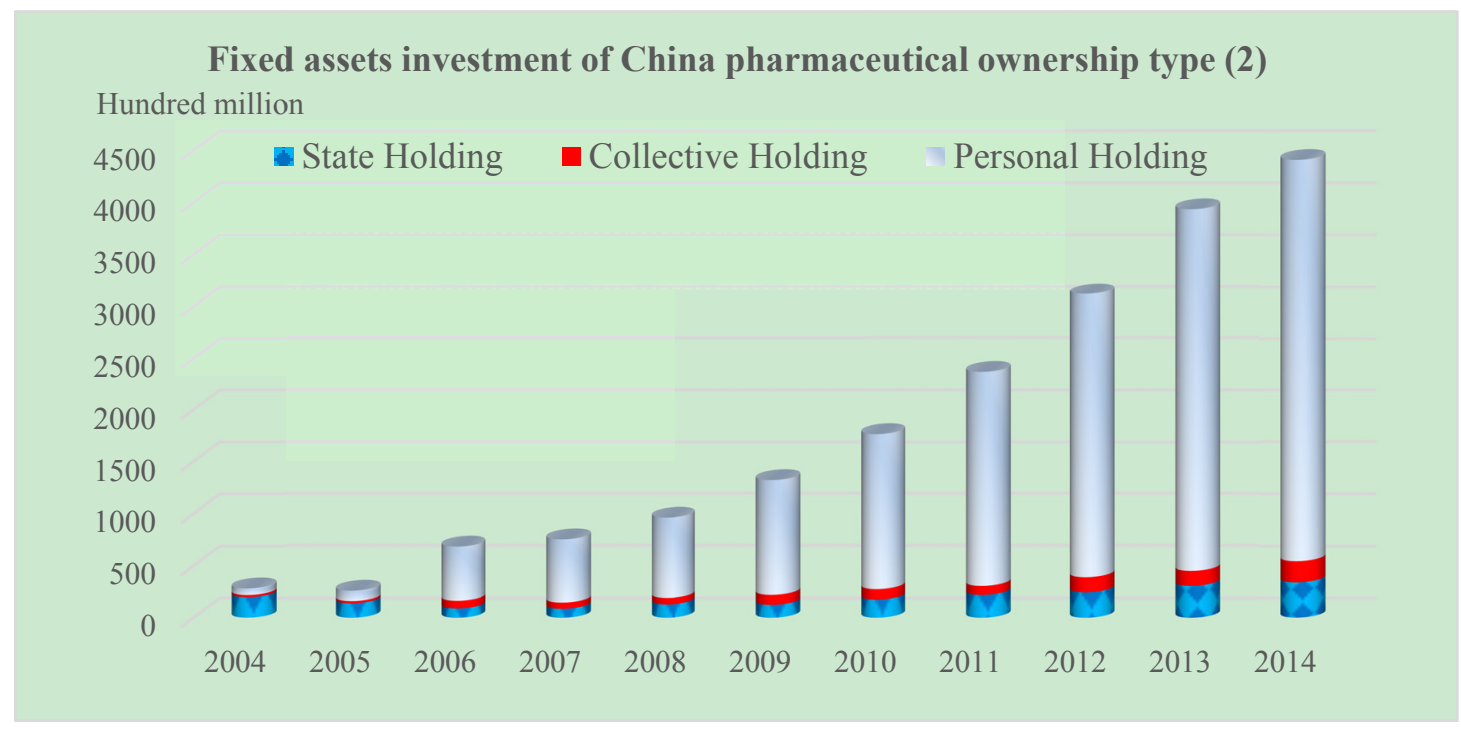

Figure 5. Fixed asset investment in ownership of pharmaceutical industry

Source: China Investment Almanac (2015).

\subsection{Construct "Stock Adjustment" State-owned Mobile Platform}

State-owned enterprises are the biggest stock resources for China's medicine economic growth. Upon state-owned pharmaceutical companies lack sufficient vigor and the competitiveness is not strong enough, the state-owned enterprises should take the development of the mixed ownership economic as the important artifice to achieve the structure adjustment and to further enhance the degree of concentration in the pharmaceutical Economy.

It is feasible for the mixed ownership structure adjustment of state-owned pharmaceutical companies is to make the overall enterprise on the market and the state-owned capital flow. Continue to raise the level of state-owned pharmaceutical capital securities, increase the intensity of reform and restructuring of state-owned pharmaceutical companies. We can learn from Shanghai and other state-owned enterprise reformation and attempt to establish a nationwide open, transparent, standardized state-owned mobile platform. ${ }^{[17]}$ Using the 
state-owned mobile platform operating mechanism to play the market allocation of resources, and it is also benefit to promote the open market-oriented reorganizations and integrations between state-owned holding companies and non-listed companies. The virtuous cycle among resources, assets, capital and cash would be a strong support for the development of strategic emerging industries and high-tech industries.

\section{Conclusion}

Although experienced 60 years reformation of pharmaceutical management system and ownership for state-owned pharmaceutical companies, the state-owned pharmaceutical companies is also Lack of vitality and competitiveness, and the mode of production is the extensive mode of production, which needs the stock adjustment in the industry structure. Reform the mixed ownership is an effective means to stimulate innovation and improve the competitiveness of state-owned enterprises, which is definitely proposed in the third plenary session of the 18th CPC Congress. The reformation of ownership for state-owned enterprises is the merges and restricting for organizational structure in micro level among enterprises, but in this process, the state-owned enterprises must give consideration to regional stock adjustment, social capital in macro level and the effective industry structure of market allocation in promoting state-owned assets.

\section{References}

Fama, E. F., \& French, K. R. (n.d.). Testing Trade-off and Pecking Order Predictions about Dividends and Debt. Review of Financial Studies, (15), 1-33.

Fang, J. X. (2007). Ownership, institutional environment and credit funds allocation. Economic Research, (12), $82-92$.

Gao, T. M. (2009). Econometric Methods and Modeling. Beijing: Tsinghua University Press.

He, D. A. (2005). Operation Mechanism Investment Analysis Introduction. Shanghai: Shanghai Sanlian Press.

Hu, J. Y., \& Qiu, J. X. (2013). Value of Upgrading Path of China's pharmaceutical industry in the global value chain. Northern Economy and Trade, (4), 19-22.

Jin, B., Lv, T., \& Deng, Z. (2011). China's industrial restructuring and upgrading: Progress, Problems and Trends. China Industrial Economy, (2), 5-15.

Li, Y. Y. (2013). Investment conduction cycle for variations industrial structure from the transaction cost perspective. Knowledge Economy, (21), 88-89.

Ma, K. (1997). Incremental adjustments and stock adjustment. Macroeconomic management (Economics Digest), (9), 10-11.

Wang, G. P. (2014). Models of industrial upgrading and Rational Choice. Shanghai Administration Institute, (1), 4-12.

Wang, G. P., \& Li, F. (2015). China's new medical reform objectives pharmaceutical products based on the analysis of structural adjustment path. Shanghai Institute of Technology (Natural Science), 15(2), 2-6.

Wang, G. P., Li, F., \& Luo, W. H. (2014). Analysis of Chinese Medical Industry Structure Adjustment Based on the path of economic restructuring. Chinese Pharmaceutical Affairs, 28(1), 18-25.

Wang, S. H. (2014). Transformation and upgrading of the manufacturing sector in incremental adjustments and stock adjustment. Modern Economic Research, (6), 38-41.

Wang, Y., \& Wang, Y. L. (2011). Path of Power and Ownership Structure Adjustment under Chinese mode. Western Forum, 21(5), 24-34.

$\mathrm{Wu}, \mathrm{Y}$. (2015). Legal Questions asked to state-owned enterprises in "mixed change". Tribune, (1), 4-12.

$\mathrm{Xu}, \mathrm{H}$. F., \& Wang, X. (2015). Regional factors layout structural convergence and influence of pharmaceutical industry. Chinese Journal of New Drugs, 24(7), 730-736.

Zhang, C., \& Liu, Z. B. (2014). Economic Analysis of Market Mechanism Forced Industrial Structure Adjustment. Social Science, (2), 47-55.

Zhong, J. W. (2012). Ownership dynamic adjustment on Capital Structure. Modern Business Trade Industry, (9), 25-26. 


\section{Copyrights}

Copyright for this article is retained by the author(s), with first publication rights granted to the journal.

This is an open-access article distributed under the terms and conditions of the Creative Commons Attribution license (http://creativecommons.org/licenses/by/4.0/). 